\title{
GAMBARAN PERILAKU HIDUP BERSIH DAN SEHAT (PHBS) MASYARAKAT PESISIR DI KEL. MATA \& KEL. KESSILAMPE KEC. KENDARI KOTA KENDARI
}

\author{
Hariati Lestari ${ }^{1}$, Yasnani ${ }^{2}$ \\ ${ }^{1}$ Bagian Epidemiologi Fakultas Kesehatan Masyarakat Universitas Halu Oleo Kendari \\ ${ }^{2}$ Bagian Kesehatan Lingkungan Fakultas Kesehatan Masyarakat Universitas Halu Oleo Kendari \\ ${ }^{1}$ lestarihariati@yahoo.co.id, 2yasnani_rahabuddin@yahoo.com
}

\begin{abstract}
Abstrak
Perilaku hidup bersih dan sehat seseorang sangat berkaitan dengan peningkatkan kesehatan individu, keluarga, masyarakat dan lingkungannya. Perilaku Hidup Bersih dan Sehat (PHBS) adalah semua perilaku yang dilakukan atas kesadaran setiap anggota keluarga, sehingga setiap anggota keluarga dapat berperan aktif pada setiap kegiatan kesehatan di masyarakat. Pemberdayaan PHBS harus dimulai dari tatanan rumah tangga, karena keluarga sehat menjadi aset pembangunan bangsa. PHBS merupakan program promosi kesehatan. Kebersihan dan kesehatan sangat berkaitan hubungannya dalam mewujudkan kesehatan masyarakat, mulai dari diri sendiri, orang lain, maupun lingkungan dan sosial. Jika PHBS di remehkan, maka banyak virus atau bakteri penyakit yang akan terjadi di masyarakat. Indikator PHBS di lingkungan masyarakat meliputi; mencuci tangan dengan air yang mengalir dan menggunakan sabun, mengkonnsumsi air yang bersih, menggunakan jamban yang bersih dan sehat, olah raga yang teratur dan terukur, tidak merokok, persalinan dengan tenaga kesehatan, pemberian ASI eksklusif pada bayi, pemantauan pertumbuhan bayi atau balita, dan membuang sampah pada tempatnya. Kelurahan Kessilampe merupakan kelurahan dengan penduduk terbanyak ke dua dari Kelurahan Kendari Cadi untuk kecamatan Kendari. Sedangkan Kelurahan Mata merupakan salah satu kelurahan yang ada di Kecamatan Kendari dengan luas wilayah $1.514 \mathrm{Ha}$, yang terdiri dari 4 RW dan 12 RT (profil Kelurahan Mata 2014). Tujuan penelitian ini adalah untuk mengetahui gambaran pengetahuan tentang Perilaku Hidup Bersih dan Sehat (PHBS) masyarakat pesisir di Kelurahan Mata dan Kelurahan Kessilampe Kecamatan Kendari Kota Kendari. Penelitian ini menggunakan metode penelitian deskriptif. Penelitian ini dilakukan di Kelurahan Mata dan Kelurahan Kessilampe Kecamatan Kendari Kota Kendari. Populasi dalam penelitian ini adalah 200 responden dari masing-masing kelurahan. 100 responden dari Kelurahan Mata dan 100 responden dari 100 Kelurahan Kessilampe.
\end{abstract}

Kata kunci: perilaku hidup bersih dan sehat, masyarakat pesisir, kel. Mata dan kel. Kessilampe

\begin{abstract}
Someone's clean and healthy living behaviors (PHBS) is pertaining with the improvement of individual, family, community, and environment health. Clean and Healthy Behavior are all behaviors done on the awareness of each member family, so every family member can play an active role in every activity health in the community. PHBS empowerment must be starting from the household order, because Healthy families become a development asset nation. PHBS is a health promotion program. Hygiene and health are closely related to the realization of public health, starting from oneself, others, and the environment and social. If PHBS is underestimated, many viruses or bacterial diseases will occur in the community. PHBS indicators in the community include; washing hands with running water and using soap, consuming clean water, using clean and healthy latrines, regular and measured exercise, not smoking, childbirth with health personnel, exclusive breastfeeding for infants, monitoring of infant or toddler growth, and Throw garbage in its place. Kessilampe Village is the Village with the second most population from Kendari Cadi for Kendari sub-district. While the Mata Village is one of the Villages in Kendari District with an area of 1,514 Ha, consisting of 4 RWs and 12 RTs (profile Mata Village 2014). The purpose of this study was to determine the description of knowledge about Clean and Healthy Life Behavior (PHBS) of coastal communities in Kelurahan Mata and Kelurahan Kessilampe, Kendari District, Kendari City. This research uses descriptive research method. Research this was done in Mata and Kessilampe Villages, Kendari District. The population in this study were 200 respondents from each village. 100 respondents from Mata Village and 100 respondents from 100 Kessilampe Village.
\end{abstract}

Keywords: clean and healthy life behavior, coastal communities, kel. Mata and kel. Kessilampe 


\section{PENDAHULUAN}

Perilaku Hidup Bersih dan Sehat (PHBS) adalah semua peilaku yang dilakukan atas kesadaran setiap anggota keluarga, sehingga setiap anggota keluarga dapat berperan aktif pada setiap kegiatan kesehatan di masyarakat ${ }^{1}$.

Menurut Raksanagara \& Raksanagara, (2015) dalam Zhafirah, N., \& Susanna, D. (2020) bahwa Untuk menerapkan PHBS dalam kehidupan seharihari, diperlukan konstribusi dari seluruh anggota keluarga, untuk meningkatkan kesadaran masyarakat mengenai hidup bersih dan sehat sehingga berperan aktif dalam bidang kesehatan masyarakat. Gerakan PHBS menjadi tolak ukur dalam pembangunan kesehatan demi meningkatkan perilaku masyarakat. HL Blum menyatakan bahwa status kesehatan individu erat kaitannya dengan perilakunya, semakin baik perilaku yang berhubungan dengan kesehatan maka status kesehatannya akan semakin baik ${ }^{2}$.

Menciptakan hidup sehat sebenarnya sangatlah mudah serta murah, apabila dibandingkan dengan biaya yang harus dikeluarkan untuk pengobatan apabila mengalami gangguan kesehatan cukup mahal. Hidup sehat merupakan hal yang seharusnya diterapkan oleh setiap orang, mengingat manfaat yang ditimbulkan akan sangat banyak, mulai dari konsentrasi kerja, kesehatan dan kecerdasan anak sampai dengan keharmonisan keluarga (Natsir, 2019). PHBS di Rumah Tangga merupakan upaya untuk memberdayakan anggota rumah tangga agar tahu, mau dan mampu mempraktikkan perilaku hidup bersih dan sehat serta berperan aktif dalam gerakan kesehatan di masyarakat. PHBS di Rumah Tangga dilakukan untuk mencapai Rumah Tangga berperilaku hidup bersih dan sehat Perilaku hidup bersih dan sehat seseorang sangat berkaitan dengan peningkatkan kesehatan individu, keluarga, masyarakat dan lingkungannya. Menurut teori HL BLUM diketahui bahwa status kesehatan individu erat kaitanya dengan perilakunya, semakin baik perilaku yang berhubungan dengan kesehatan maka status kesehatanya akan semakin baik ${ }^{3}$.

Pemberdayaan PHBS harus dimulai dari tatanan rumah tangga, karena keluarga sehat menjadi aset pembangunan bangsa(Hidayah, 2019). Setiap anggota keluarga memiliki masa rawan tersendiri terhadap serangan penyakit menular maupun tidak menular, sehingga anggota keluarga perlu diberdayakan untuk melaksanakan PHBS (Nurhajati, 2019). Materi PHBS dapat beragam. Sepuluh indikator PHBS di rumah tangga meliputi: 1.
Pertolongan persalinan oleh tenaga kesehatan; 2. Memberi bayi ASI eksklusif; 3. Menimbang balita setiap bulan; 4. Menggunakan air bersih; 5 . Mencuci tangan dengan air dan sabun; 6. Menggunakan jamban sehat; 7. Memberantas jentik di rumah sekali seminggu; 8 . Makan buah dan sayur setiap hari; 9. Melakukan aktivitas fisik setiap hari; dan 10. Tidak merokok di dalam rumah (Gunawan et al., 2018). Program "Perilaku Hidup Bersih dan Sehat (PHBS)" memiliki tujuan yaitu menambah pengetahuan pada masyarakat tentang Perilaku Hidup Bersih Dan Sehat (PHBS), membiasakan masyarakat membuang sampah yang benar, menciptakan lingkungan yang indah, bersih, dan sehat ${ }^{4}$.

Sulawesi Tenggara salah satu provinsi yang masih rendah cakupan PHBSnya yaitu hanya mencakup $43,8 \%$ jika dibandingkan dengan standar cakupan Indonesia yaitu 55\%. Berdasarkan laporan hasil pemantauan dinas kesehatan kabupaten/kota di Provinsi Sulawesi Tenggara tahun 2014 yang dilaksanakan pada sejumlah desa yang tersebar pada 12 kabupaten/kota dengan jumlah Rukun Tetangga (RT) yang dipantau sebanyak 233.709 menunjukkan hanya 117.925 RT $(50,46 \%)$ yang ber-PHBS, jumlah ini relatif meningkat dari tahun 2013 yang hanya 90.006 RT (36.83\%). Data tersebut menunjukkan cakupan Rumah Tangga yang ber-PHBS di Provinsi Sulawesi Tenggara relatif masih rendah, hal ini berpengaruh terhadap kesehatan masyarakat secara umum, serta kejadian penyakit menular maupun penyakit tidak menular ${ }^{5}$.

Secara geografis kelurahan kessilampe terletak di sebelah barat. Kelurahan Kessilampe merupakan kelurahan dengan penduduk terbanyak kedua dari kelurahan kendari cadi untuk kecamatan Kendari. Luas wilayah menurut penggunaan di Kelurahan Kessilampe Kecamatan Kendari terbagi atas luas pemukiman, luas kuburan, luas pekarangan, luas perkantoran, dan luas prasarana umum lainnya. Dimana luas pemukiman seluas 153 $\mathrm{Ha}$, luas kuburan $0,5 \mathrm{Ha}$, luas pekarangan seluas 5 $\mathrm{Ha}$, luas perkantoran seluas $2,6 \mathrm{Ha}$, dan luas prasarana umum lainnya seluas $69,9 \mathrm{Ha}$. Dengan total luaswilayah secara keseluruhan adalah $231 \mathrm{Ha}$. Sedangkan Kelurahan Mata merupakan salah satu kelurahan yang ada di Kecamatan Kendari dengan luas wilayah $1.514 \mathrm{Ha}$, yang terdiri dari 4 RW dan 12 RT menurut profil Kelurahan Mata dalam laporan PBL 1 (2019). Batas Wilayah Kelurahan Mata terletak $\pm 4 \mathrm{Km}$ dari Ibu Kota Kecamatan Kendari dengan luas wilayah $3.292 \mathrm{Ha}$. Tujuan penelitian ini 
adalah untuk mengetahui gambaran perilaku hidup bersih dan sehat (PHBS) masyarakat pesisir di Kel. Mata \& Kel. Kessilampe, Kec. Kendari, Kota Kendari.

\section{METODE}

Penelitian ini menggunakan metode penelitian deskriptif, maka dapat disusun kerangka pikir yang menggambarkan tentang PHBS itu sendiri. Penelitian deskriptif yaitu mengumpulkan data berdasarkan faktor-faktor yang menjadi pendukung terhadap objek penelitian, kemudian menganalisa faktor-faktor tersebut untuk dicari peranannya. Data yang diperoleh peneliti melalui observasi, adapun data yang diperoleh dari hasil penelitian yaitu wawancara yang berasal dari data laporan PBL FKM UHO Angkatan 2017 di Kelurahan Mata dan Kelurahan Kessilampe, Kecamatan Kendari, Kota Kendari.

Penelitian ini dilakukan di Kelurahan Mata dan Kelurahan Kessilampe Kecamatan Kendari Kota Kendari. Populasi dalam penelitian ini adalah 200 responden dari masing-masing kelurahan. 100 responden dari Kelurahan Mata dan 100 responden dari 100 Kelurahan Kessilampe. Variabel dalam penelitian ini adalah lingkungan yang terdiri dari lingkungan fisik, sosial dan biologi tentang PHBS, dan perilaku terhadap PHBS, masyarakat di Kelurahan Mata dan Kelurahan Kessilampe. Instrumen yang digunakan untuk pengumpulan data masing-masing variabel adalah kuisioner

HASIL

Tabel 1. Distribusi Responden Menurut Jenis Kelamin di Kelurahan Mata dan Kelurahan Kessilampe Kecamatan Kendari Tahun 2019

\begin{tabular}{lcc}
\hline Jenis kelamin & Jumlah (n) & (\%) \\
\hline Laki- Laki & 114 & 57 \\
\hline Perempuan & 86 & 43 \\
\hline \multicolumn{1}{c}{ Total } & $\mathbf{2 0 0}$ & $\mathbf{1 0 0}$
\end{tabular}

Sumber: Data Sekunder PBL 1 Kelurahan Mata dan Kelurahan Kessilampe tahun 2019

Berdasarkan tabel di atas, menunjukkan bahwa dari 200 responden, distribusi responden menurut jenis kelamin yang paling banyak yaitu lakilaki dengan jumlah 114 responden atau 57\% dan perempuan dengan jumlah 86 responden atau $43 \%$.
Tabel 2. Distribusi Responden Menurut Pekerjaan di Kelurahan Mata dan Kassilampe Kecamatan Kendari Tahun 2019

\begin{tabular}{lcc}
\hline Pekerjaan & Jumlah (n) & \% \\
\hline lbu Rumah Tangga & 129 & 64,5 \\
\hline Pegawai Negeri Sipil & 18 & 9 \\
\hline Karyawan Swasta & 7 & 3,5 \\
\hline $\begin{array}{l}\text { wiraswasta/pemilik } \\
\text { salon/bengkel }\end{array}$ & 14 & 7 \\
\hline $\begin{array}{l}\text { Berdagang/pemilik } \\
\text { warung }\end{array}$ & 5 & 2,5 \\
\hline $\begin{array}{l}\text { Buruh/sopir/tukang/ } \\
\text { ojek }\end{array}$ & 1 & 0,5 \\
\hline Nelayan & 9 & 4,5 \\
\hline Pelajar & 2 & 1 \\
\hline Honorer & 1 & 0,5 \\
\hline Tidak bekerja & 10 & 5 \\
\hline lain-lain & 4 & 2 \\
\hline \multicolumn{1}{c}{ Total } & $\mathbf{2 0 0}$ & $\mathbf{1 0 0}$ \\
\hline
\end{tabular}

Sumber: Data Sekunder PBL 1 Kelurahan Mata dan Kassilampe tahun 2019

Berdasarkan tabel diatas, menunjukkan bahwa responden paling banyak bekerja sebagai ibu rumah tangga dengan jumlah 129 responden atau $64,5 \%$, sedangkan pekerjaan yang paling sedikit adalah buruh/sopir/tukang ojek dan honorer dengan jumlah masing-masing 1 responden atau 0,5\%.

Table 3. Distribusi Responden Menurut Jumlah Pendapatan Per Jumlah Anggota Keluarga Di Kelurahan Mata dan Kessilampe Kecamatan Kendari Tahun 2019

\begin{tabular}{lcc}
\hline \multicolumn{1}{c}{ Jumlah Pendapatan } & Jumlah $(\mathbf{n})$ & $\mathbf{\%}$ \\
\hline$<$ Rp500.000 & 29 & 14,5 \\
\hline $\begin{array}{l}\text { Rp500.000- } \\
<\text { Rp1.500.000 }\end{array}$ & 84 & 42 \\
\hline$>$ Rp1.500.000 & 87 & 43,5 \\
\hline $\begin{array}{l}\text { Tidak punya } \\
\text { penghasilan }\end{array}$ & 0 & 0 \\
\hline \multicolumn{1}{c}{ Total } & $\mathbf{2 0 0}$ & $\mathbf{1 0 0}$ \\
\hline
\end{tabular}

Sumber: Data Sekunder PBL 1 Kelurahan Mata dan Kassilampe tahun 2019

Tabel 3. menunjukan bahwa dari 100 responden, jumlah penghasilan responden yang paling sedikit berada pada kelompok jumlah pendapatan < Rp 500.000 sebanyak 29 responden dengan persentase $14,5 \%$ dan penghasilan 
responden yang paling banyak berada pada kelompok jumlah pendapatan >Rp. 1.500 .000 sebanyak 87 responden dengan persentase $43,5 \%$.

Tabel 4. Distribusi Responden Menurut Persalinan Ditolong oleh Tenaga Kesehatan di Kelurahan Mata dan Kelurahan Kessilampe Kecamatan Kendari Tahun 2019

\begin{tabular}{lccc}
\hline $\begin{array}{c}\text { Persalinan Ditolong oleh } \\
\text { Tenaga Kesehatan }\end{array}$ & Jumlah (n) & (\%) \\
\hline $\mathrm{Ya}$ & 118 & 91 \\
\hline Tidak & Total & 11 & 9 \\
\hline \multicolumn{2}{r}{} & $\mathbf{1 2 9}$ & $\mathbf{1 0 0}$ \\
\hline
\end{tabular}

Sumber: Data Sekunder PBL 1 Kelurahan Mata dan Kelurahan Kessilampe tahun 2019

Berdasarkan tabel di atas, distribusi persalinan responden yang ditolong oleh tenaga kesehatan dari 129 responden yang mempunyai balita terdapat 118 responden atau 91\% yang persalinannya ditolong oleh tenaga kesehatan, sedangkan 11 responden atau 9\% tidak di tolong oleh tenaga kesehatan.

Tabel 5. Distribusi Responden Menurut Pemberian ASI Eksklusif pada Bayi Di Kelurahan Mata dan Kelurahan Kessilampe Tahun 2019

\begin{tabular}{|c|c|c|}
\hline Pemberian ASI Eksklusif & Jumlah (n) & (\%) \\
\hline Ya & 109 & 84,5 \\
\hline Tidak & 20 & 15,5 \\
\hline Total & 129 & 100 \\
\hline
\end{tabular}

Sumber: Data Sekunder PBL 1 Kelurahan Mata dan Kelurahan Kessilampe tahun 2019

Berdasarkan tabel distribusi responden menurut pemberian asi eksklusif pada bayi dari 129 reponden, terdapat 109 responden dengan presentase $84,5 \%$ memberikan asi eksklusif kepada bayinya. Sedangkan 20 responden dengan presentase $15,5 \%$ tidak memberikan asi eksklusif kepada bayinya.
Tabel 6. Distribusi Responden Menurut Perlakuan Pemantauan Pertumbuhan Bayi atau Balita di Kelurahan Mata dan Kelurahan Kessilampe Kecamatan Kendari Tahun 2019

\begin{tabular}{ccc}
\hline $\begin{array}{c}\text { Pemantauan } \\
\text { Pertumbuhan Bayi atau } \\
\text { Balita }\end{array}$ & Jumlah (n) & (\%) \\
\hline Ya & 115 & 89 \\
\hline Tidak & 14 & 11 \\
\hline Total & $\mathbf{1 2 9}$ & $\mathbf{1 0 0}$ \\
\hline
\end{tabular}

Sumber: Data Sekunder PBL 1 Kelurahan Mata dan Kelurahan Kessilampe tahun 2019

Berdasarkan tabel di atas dari 200 responden yang diwawancarai terdapat 129 rumah tangga yang memiliki bayi atau balita. Berdasarkan tabel, menunjukkan bahwa dari 129 responden, terdapat 115 responden atau 89\% yang melakukan pemantauan pertumbuhan bayi atau balita, sedangkan 14 responden atau 11\% tidak melakukan pemantauan pertumbuhan bayi atau balita dan 71 responden tidak memiliki bayi atau balita.

Tabel 7. Distribusi Responden Menurut Anggota Keluarga Yang Merokok di Kelurahan Mata dan Kelurahan Kessilampe Kecamatan Kendari Tahun 2019

\begin{tabular}{lccc}
$\begin{array}{c}\text { Anggota Keluarga yang } \\
\text { Merokok }\end{array}$ & Jumlah (n) & \% \\
\hline Ya & 126 & 63 \\
\hline Tidak & Total & 74 & 37 \\
\hline & $\mathbf{2 0 0}$ & $\mathbf{1 0 0}$ \\
\hline
\end{tabular}

Sumber: Data Sekunder PBL 1 Kelurahan Mata dan Kelurahan Kessilampe 2019

Berdasarkan tabel diatas, menunjukkan bahwa dari 200 responden, terdapat 126 responden atau $63 \%$ yang merokok, sedangkan 74 responden atau $37 \%$ tidak merokok. 
Tabel 8. Distribusi Responden Menurut Akses sarana Air Bersih Di Kelurahan Mata dan Kelurahan Kessilampe Tahun 2019

\begin{tabular}{|c|c|c|}
\hline $\begin{array}{l}\text { Memiliki Akses } \\
\text { sarana Air Bersih }\end{array}$ & Jumlah (n) & (\%) \\
\hline $\mathrm{Ya}$ & 194 & 97 \\
\hline Tidak & 6 & 3 \\
\hline Total & 200 & 100 \\
\hline
\end{tabular}

Sumber: Data Sekunder PBL 1 Kelurahan Mata dan Kelurahan Kessilampe tahun 2019

Pada tabel di atas, dari 200 responden ada 194 atau 97\% keluarga responden yang memiliki sarana air bersih dan ada 6 responden atau 3\% yang tidak memiliki akses sarana air bersih.

Tabel 9. Distribusi Responden Menurut Penggunaan Jamban Ketika Buang Air Besar (BAB) Di Kelurahan Mata dan Kelurahan Kessilampe Tahun 2019

Penggunaan Jamban

Ketika Buang Air Besar Jumlah (n)

(\%)

(BAB)

\begin{tabular}{lccc}
\hline Ya & 196 & 98 \\
\hline Tidak & & 4 & 2 \\
\hline & Total & $\mathbf{2 0 0}$ & $\mathbf{1 0 0}$ \\
\hline
\end{tabular}

Sumber: Data Sekunder PBL 1 Kelurahan Mata dan Kelurahan Kessilampe tahun 2019

Berdasarkan tabel diatas, dari 200 responden terdapat 196 responden atau 98\% yang menggunakan jamban ketika Buang Air Besar (BAB), sedangkan 4 responden atau $2 \%$ yang tidak menggunakan jamban ketika Buang Air Besar (BAB).

\section{PEMBAHASAN}

Distribusi Responden Menurut Jenis Kelamin di Kelurahan Mata dan Kelurahan Kessilampe Kecamatan Kendari Tahun 2019

Perilaku Hidup Bersih dan Sehat (PHBS) adalah semua perilaku kesehatan yang dilakukan karena kesadaran pribadi sehingga keluarga dan seluruh anggotanya mampu menolong diri sendiri pada bidang kesehatan serta memiliki peran aktif dalam aktivitas masyarakat. Perilaku Hidup Bersih dan Sehat ini pada dasarnya merupakan sebuah upaya untuk menularkan pengalaman mengenai pola hidup sehat melalui individu, kelompok ataupun masyarakat luas dengan jalur-jalur komunikasi sebagai media informasi.

Berdasarkan data yang telah diperoleh pada Kelurahan Mata dan Kelurahan Kessilampe di Kota Kendari, dapat diketahui bahwa dari 200 responden, distribusi responden menurut jenis kelamin yang paling banyak pada daerah ini yaitu laki-laki dengan jumlah 114 responden atau 57\%, sedangkan perempuan berjumlah 86 atau $43 \%$.

Distribusi Responden Menurut Pekerjaan Di Kelurahan Mata dan Kassilampe Kecamatan Kendari Tahun 2019

Lingkungan pekerjaan dapat menjadikan seseorang memperoleh pengalaman dan pengetahuan baik secara langsung maupun tidak langsung. Dalam memenuhi kebutuhan rumah tangga ber-PHBS diharapkan pekerjaan dapat meningkatkan upaya penerapan PHBS dalam tatanan rumah tangga. Pada Kelurahan Mata dan Kelurahan Kessilampe ini, masyarakatnya dominan bekerja sebagai Ibu Rumah Tangga dengan jumlah 129 orang atau $64,5 \%$ dan yang terendah yaitu sebagai buruh/sopir/tukang/ojek dan honorer yaitu 0,5\%.

Pekerjaan merupakan suatu profesi yang digeluti oleh seseorang untuk mendapatkan penghasilan yang berguna untuk memenuhi kebutuhannya.Pada masyarakat di Kecamatan Mata \& Kecamatan Kessilampe yang dominan bekerja sebagai Ibu Rumah Tangga, ibu mempunyai peran yang sangat penting untuk membangun perilaku hidup sehat dalam keluarga dan memelihara kesehatan keluarganya.Ibu memainkan peran penting sebagai pemberi asuhan primer untuk semua anggota keluarga. Ibu yang bekerja di rumah, akan memiliki lebih banyak waktu dalam mengurus kebutuhan rumah tangga termasuk mendidik keluarganya untuk berperilaku hidup bersih dan sehat $^{8}$.

Kemampuan anak untuk menerapkan indikaor PHBS dipengaruhi oleh pekerjaan ibu ${ }^{8}$. Seiring dengan perkembangan zaman, perempuan bekerja merupakan salah satu hal yang biasa baik di 
luar maupun du dalam rumah. Beberapa perempuan yang bekerja di luar rumah bahkan mampu meduduki posisi penting dalam berbagai jabatan di sektor swasta maupun pemerintahan. Keterlibatan perempuan untuk bekerja, dikarenakan keinginan mereka untuk mencukupi kebutuhan perekonomian keluarga ${ }^{9}$.

Pekerjaan dapat memberikan pengaruh besar bagi seseorang, dimana sesorang dapat mempelajari banyak hal yang baik dan juga hal-hal yang buruk tergantung pada sifat kelompok lingkungan kerjanya. Selain itu, pekerjaan juga dapat memberikan pendapatan kepada seseorang untuk memenuhi kebutuhan hidupnya termasuk kebutuhan untuk menunjang perilaku hidup bersih dan sehat. Pada kedua kelurahan ini, sebagian besar masyarakatnya sudah mendapatkan pekerjaan yang memadai sehingga mereka dapat memenuhi kebutuhan mereka dengan baik untuk menunjang kesehatan dan kesejahteraannya.

Distribusi Responden Menurut Jumlah Pendapatan Per Jumlah Anggota Keluarga Di Kelurahan Mata dan Kessilampe Kecamatan Kendari Tahun 2019

Pendapatan seseorang merupakan tolak ukur yang penting dalam melaksanakan berbagai kegiatan. Hal ini erat kaitannya dengan jumlah uang yang diperoleh yang digunakan sebagai biaya operasional sehari-hari. Apabila keluarga dengan pendapatan <UMR maka hal tersebut berdampak terhadap adanya kemungkinan keluarga untuk mengesampingkan kebutuhan yang dianggap tidak begitu urgen, artinya keluarga lebih mengutamakan kebutuhan primer (pangan dan papan) baru kemudian kebutuhan lain yang dianggap penting. Oleh karena itu pemahaman tidak penting inipun turut mempengaruhi keputusan keluarga dalam berperilaku hidup sehat maupun tidak sehat diantaranya pelaksanaan PHBS ${ }^{10}$.

Data menunjukan bahwa dari 200 responden, jumlah penghasilan responden yang paling sedikit berada pada kelompok jumlah pendapatan < Rp 500.000 sebanyak 29 responden dengan persentase $14,5 \%$ dan penghasilan responden yang paling banyak berada pada kelompok jumlah pendapatan
$>$ Rp 1.500 .000 sebanyak 87 responden dengan persentase $43,5 \%$.

Tingkat pendapatan masyarakat ini akan sangat berpengaruh terhadap perubahan sikap menuju perilaku hidup bersih dan sehat. Tingkat pendapatan yang rendah akan mempengaruhi masyarakat dalam memperoleh dan mencerna informasi untuk kemudian menentukan pilihan dalam menerapkan hidup sehat. Tingkat pendapatan ini berkaitan dengan kemiskinan yang akan berpengaruh pada status kesehatan masyarakat. Pendapatan juga merupakan salah satu faktor yang mempengaruhi tingkat wawasan masyarakat mengenai sanitasi lingkungan.

Pendapatan merupakan faktor yang berhubungan dengan kualitas PHBS. Pendapatan masyarakat pada kedua kelurahan ini tergolong dalam kelompok masyarakat berpenghasilan menengah dengan jumlah pendapatan $>$ Rp 1.500 .00 sebanyak 87 responden dengan presentase 43,5\% sehingga pemenuhan kebutuhan sudah cukup. Bila ditinjau dari faktor sosial ekonomi, maka pendapatan merupakan suatu faktor yang mempengaruhi tingkat wawasan masyarakat mengenai kesehatan lingkungan.Hal ini juga sesuai dengan pendapat bahwa tingkat pendapatan berkaitan dengan kemiskinan yang berpengaruh pada status kesehatan.

Distribusi Responden Menurut Persalinan Ditolong oleh Tenaga Kesehatan di Kelurahan Mata dan Kelurahan Kessilampe Kecamatan Kendari Tahun 2019

Tenaga kesehatan adalah orang yang bekerja secara aktif dan profesional dalam bidang kesehatan. Profesional sendiri diartikan sebagai tindakan yang dapat dipertanggung jawabkan, didasari oleh keyakinan, kompeten, tepat atau taat asas, cermat, intelektual atau cerdas, etos kerja, percaya diri atas kemampuan, optimistik, bermoral, dan bersikap serta berpikir positif.

Pemilihan penolong persalinan merupakan salah satu upaya yang dilakukan untuk mencari pertolongan dalam menghadapi proses persalinan. Pemilihan tenaga penolong persalinan merupakan salah satu hak reproduksi perorangan dalam 
menentukan dimana akan melahirkan serta siapa yang akan menolong persalinan. Persalinan yang aman memastikan bahwa semua penolong persalinan mempunyai pengetahuan, keterampilan dan alat untuk memberikan pertolongan yang aman dan bersih, serta memberikan pelayanan nifas kepada ibu dan bayi.

Pemilihan tenaga penolong persalinan pada tenaga non kesehatan (dukun bayi) sering kali menimbulkan dampak yang akan menyebabkan angka kesakitan ibu dan bayi, juga komplikasi persalinan, bahkan kematian pada ibu bersalin dan bayinya. Dapat dipahami bahwa dukun bayi tidak dapat mengetahui tanda-tanda bahaya persalinan, akibatnya terjadi pertolongan persalinan yang tidak adekuat.Hal ini merupakan salah satu penyebab tidak langsung kematian ibu dan bayi baru lahir.

Berdasarkan tabel, distribusi persalinan responden yang ditolong oleh tenaga kesehatan dari 129 responden yang mempunyai balita terdapat 118 responden atau 91\% yang persalinannya ditolong oleh tenaga kesehatan, sedangkan 11 responden atau $9 \%$ tidak di tolong oleh tenaga kesehatan.

\section{Distribusi Responden Menurut Pemberian ASI Eksklusif pada Bayi Di Kelurahan Mata dan Kelurahan Kessilampe Tahun 2019}

Menurut WHO (2002) dalam Hanulan Septiani, dkk. (2017) bahwa ASI adalah makanan alami pertama untuk bayi yang memberikan semua vitamin, mineral dan nutrisi yang diperlukan oleh bayi untuk pertumbuhan dalam enam bulan pertama dan tidak ada makanan atau cairan lain yang diperlukan. ASI memenuhi setengah atau lebih kebutuhan gizi anak pada tahun pertama hingga tahun kedua kehidupan. Menurut Gupta, (2013) dalam Hanulan Septiani, dkk. (2017) bahwa disamping kandungan nutrisi yang lengkap didalam ASI juga terdapat zat kekebalan seperti $\lg A, \lg M$, IgG, IgE, laktoferin, lisosom, immunoglobulin dan zat lainnya yang melindungi bayi dari berbagai penyakit infeksi. Lebih dari 136 juta bayi lahir setiap tahunnya, dan sekitar 92 juta diantaranya tidak mendapatkan ASI eksklusif sampai 6 bulan.

Berdasarkan data Riset Kesehatan Dasar (Riskesdas, 2013) pemberian ASI eksklusif pada bayi usia 0-1 bulan 48,7\%, pada usia 2-3 bulan menurun menjadi $42,2 \%$ dan semakin menurun seiring dengan meningkatnya usia bayi yaitu $36,6 \%$ pada bayi berusia 4-5 bulan dan 30,2\% pada bayi usia 6 bulan. Pada tahun 2009 pencapaian cakupan ASI eksklusif sebesar 34, 3 \% dan menurun pada 2010 menjadi 33, 6\% (BPS, Susenas 2010). Sedangkan Hasil Riset Kesehatan Dasar tahun 2013 jauh lebih rendah lagi yaitu 30, 2 \%.(Riskesdas, 2013). Angka tersebut masih jauh dari target cakupan ASI nasional yaitu sebesar $80 \%$. Bahkan berdasarkan data WBTI tahun 2012 tentang kondisi menyusui di 51 negara berdasarkan pengukuran indikator yang telah ditetapkan, Indonesia urutan ke 49 dari 51 negara dengan angka menyusui hanya sebesar $27,5 \%$ (IBFAN \& BPNI, 2012). Hal ini tentu sangat memprihatinkan mengingat Indonesia merupakan salah satu negara yang memiliki kebijakan tentang ASI yang cukup baik serta upaya- upaya program akselerasi untuk pencapaian ASI eksklusif yang sangat gencar baik dilakukan oleh pemerintah, swasta maupun Lembaga Swadaya Masyarakat (LSM) ${ }^{12}$.

Berdasarkan tabel distribusi responden menurut pemberian asi eksklusif pada bayi dari 129 reponden, terdapat 109 responden dengan presentase $84,5 \%$ memberikan asi eksklusif kepada bayinya. Sedangkan 20 responden dengan presentase $15,5 \%$ tidak memberikan asi eksklusif kepada bayinya.

Berbagai penelitian menunjukkan bahwa ibu yang bekerja lebih beresiko tidak memberikan ASI eksklusif dibandingkan ibu yang tidak bekerja, dimana ibu yang tidak bekerja lebih berpeluang untuk dapat memberikan ASI eksklusif sebesar 16,4 kali dibandingkan dengan ibu yang bekerja. Demikian pula dengan penelitian Kurniawan (2013) terdapat hubungan yang signifikan antara pekerjaan ibu dengan pemberian ASI eksklusif, yaitu ibu yang bekerja persentase pemberian ASI eksklusif lebih kecil dibandingkan dengan ibu yang tidak bekerja. Penelitian di Singapura terhadap 2149 ibu melahirkan di rumah sakit didapatkan hubungan yang signifikan bahwa ibu yang bekerja lebih mungkin untuk berhenti menyusui dibandingkan dengan ibu yang tidak bekerja ${ }^{13}$.

Keberhasilan seorang ibu dalam menyusui dipengaruhi oleh banyak faktor yaitu, factor predisposisi, faktor pemungkin dan factor penguat. Faktor predisposisi yang meliputi umur, pendidikan, pengetahuan, sikap, keterpaparan terhadap informasi.Faktor pemungkin meliputi kebijakan instansi, ketersediaan fasilitas. Sedangkan faktor penguatnya adalah adanya dukungan suami, dukungan keluarga dan yang tidak kalah pentingnya 
adalah dukungan dari tenaga kesehatan. Diantara semua faktor diatas, dukungan tenaga kesehatan mempunyai nilai odds ratio (OR) paling tinggi yaitu 23,85, artinya bahwa ibu yang mendapatkan dukungan dari tenaga kesehatan baik tenaga kesehatan penolong persalinan maupun tenaga kesehatan saat ibu kembali memeriksakan bayinya setelah pulang rawat inap dalam memfasilitasi dan mendorong ibu untuk memberikan ASI eksklusif, mempunyai peluang untuk berhasil memberikan ASI eksklusif 23,8 kali lebih besar dibandingkan dengan ibu yang tidak mendapatkan dukungan dari tenaga kesehatan. Tenaga kesehatan yang memiliki tingkat pengetahuan yang tinggi mengenai ASI eksklusif berhubungan secara signifikan terhadap dukungan pemberian ASI pada ibu menyusui ${ }^{13}$.

\section{Distribusi Responden Menurut Perlakuan Pemantauan Pertumbuhan Bayi Atau Balita Di Kelurahan Mata Dan Kelurahan Kasilampe Kecamatan Kendari 2019}

Pos Pelayanan Terpadu atau Posyandu, merupakan salah satu bentuk pelayanan kesehatan yang diselenggarakan oleh masyarakat untuk masyarakat dengan dukungan teknis dari petugas kesehatan setempat. Tujuan Posyandu antara lain adalah: mempercepat penurunan angka kematian ibu dan anak, meningkatkan pelayanan kesehatan ibu untuk menurunkan IMR, mempercepat penerimaan NKKBS, meningkatkan kemampuan masyarakat untuk mengembangkan kegiatan kesehatan dan kegiatan-kegiatan lain yang menunjang peningkatan kemampuan hidup sehat, pendekatan dan pemerataan pelayanan kesehatan kepada masyarakat dalam usaha meningkatkan cakupan pelayanan kesehatan kepada penduduk berdasarkan letak geografi, meningkatkan dan pembinaan peran serta masyarakat dalam rangka alih teknologi untuk swakelola usaha-usaha kesehatan masyarakat ${ }^{14}$.

Posyandu adalah suatu wadah komunikasi alih teknologi dalam pelayanan kesehatan masyarakat dari masyarakat dan untuk masyarakat dengan dukungan pelayanan serta pembinaan teknis dari petugas kesehatan yang mempunyai nilai strategis untuk pengembangan sumber daya manusia sejak dini dalam rangka pembinaan kelangsungan hidup anak (Child Survival) yang ditujukan untuk menjaga kelangsungan hidup anak sejak janin dalam kandungan ibu sampai usia balita, dan pembinaan perkembangan anak (Child
Development) yang ditunjukan untuk membina tumbuh kembang anak secara sempurna, baik fisik maupun mental sehingga siap menjadi tenaga kerja Tangguh ${ }^{14}$.

Berdasarkan data yang diperoleh di kelurahan mata dan kelurahan kasilampe kecamatan Kendari dari 200 responden yang di wawancarai terdapat 129 rumah tangga yang memiliki bayi atau balita. Berdasarkan table 6. Menunjukkan bahwa dari 129 responden, terdapat 115 responden atau 89\% yang melakukan pemantauan pertumbuhan bayi atau balita, sedangkan 14 responden atau 11\% tidak melakukan pemantauan pertumbuhan bayi atau balita dan 71 responden tidak memiliki bayi atau balita.

\section{Distribusi Responden Menurut Anggota Keluarga Yang Merokok Di Kelurahan Mata dan Kelurahan Kessilampe Kecamatan Kendari Tahun 2019}

Merokok merupakan suatu faktor yang memberikan dampak besar pada kesehatan terutama pada paru-paru. Asap rokok yang dihirup seorang perokok mengandung komponen gas dan partikel. Komponen gas terdiri dari karbon monoksida, karbon dioksida, hidrogen sianida, amoniak, oksida dari nitrogen dan senyawa hidrikarbon. Adapun komponen partikel terdiri daritar, nikotin, benzopiren, fenol, dan kadmium. Terdapat 4000 bahan kimia berbahaya dalam rokok. Bahan kimia yang berbahaya dalam rokok adalah nikotin merupakan zat adiktif dan tar yang bersifat karsinogenik. Racun dan karsinogen yang muncul akibat pembakaran tembakau dapat menyebabkan kanker timbulnya kanker paru-paru.Bahkan ada yang secara tegas menyatakan bahwa rokok sebagai penyebab utama terjadinya kanker paru-paru. Partikel asap rokok, seperti benzapiren, dipensapiren dan ureta, dikenal sebagai bahan karsinogen. Juga tar berhubungan dengan risiko terjadinya kanker ${ }^{15}$.

Berdasarkan data penelitian di Kelurahan Mata dan Kelurahan Kessilampe menunjukkan bahwa dari 200 responden, masih terdapat 126 responde atau $63 \%$ masyarakat yang masih merokok, sedangkan 74 responden atau $37 \%$ masyarakat yang tidak merokok. 
Distribusi Responden Berdasarkan Akses Sarana Air Bersih Di Kelurahan Mata dan Kelurahan Kessilampe Tahun 2019

Akses berkaitan erat dengan tingkat kenyamanan atau kemudahan dalam mencapai sesuatu yang ingin dicapai.Akses dapat dinyatakan dengan jarak, jika suatu tempat berdekatan dengan tempat yang lainnya, dinyatakan akses antara kedua tempat tersebut tinggi.Sebaliknya, jika kedua tempat itu saling berjauhan, maka dapat dikatakan aksesbilitas antara keduanya rendah. Jadi, penggunaan akses yang tepat dapat dinyatakan dalam jarak dan waktu tempuh ${ }^{16}$.

Akses air merupakan salah satu kebutuhan dasar yang harus mampu disediakan oleh pemerintah guna meningkatkan kesejahteraan masyarakat. Ketersediaan air yang cukup akan mempengaruhi produktifitas baik dalam sektor barang maupun jasa ${ }^{16}$.

Rumah tangga dikatakan mempunyai akses air minum yang layak apabila sumber air minum yang digunakan rumah tangga berasal dari air ledeng (keran), hydran umum, keran umum, terminal air, penampungan air hujan (PAH) atau mata air dan sumur terlindung, sumur bor atau sumur pompa, yang jaraknya minimal 10 meter dari tempat pembuangan kotoran, penampungan limbah dan pembuangan sampah. Tidak termasuk air kemasan, air dari penjual keliling, air yang dijual melalui tanki, air sumur dan mata air tidak ${ }^{17}$.

Pada tabel di atas, dari 200 responden ada 194 atau 97\% keluarga responden yang memiliki akses sarana air bersih dan ada 6 responden atau 3\% yang tidak memiliki akses sarana air bersih. Berdasarkan hasil penelitian dikatakan bahwa sarana penyediaan air bersih pada masyarakat kelurahan mata dan kelurahan kessilampe pada tahun 2019 sebagian besar masyarakat sudah memilik akses sarana air bersih dan sebagaian juga masyarakat masih ada yang belum mempunyai akses sarana air bersih.Berdasarkan hasil penelitian diketahui bahwa sarana penyediaan air bersih pada masyarakat kelurahan mata dan kelurahan kessilampe tahun 2019 sebagaian besar masyarakat sudah memiliki akses sarana air bersih yakni berjumlah 194 atau 97\%. Hal ini disebabkan masyarakat sudah memiliki kesadaran yang tinggi tentang pentingnya sarana air bersih untuk digunakan keluarga.
Distribusi Responden Menurut Penggunaan Jamban Ketika Buang Air Besar (BAB) Di Kelurahan Mata dan Kelurahan Kessilampe Tahun 2019

Permasalahan kesehatan di Indonesia masih ditandai dengan tingginya angka kesakitan dan kematian penyakit yang berbasis lingkungan. Kondisi tersebut banyak dijumpai di daerah pedesaan. Penyakit yang penularannya berkaitan dengan air dan lingkungan terutama penyakit diare masih endemis dan merupakan masalah kesehatan yang belum selesai. Berdasarkan data WHO bahwa kematian yang disebabkan karena waterborne disease mencapai 3.400.000 jiwa per tahun, dan penyakit diare merupakan penyebab kematian terbesar yaitu 1.400.000 jiwa per tahun. Dari semua kematian tersebut penyebabnya berakar pada sanitasi dan kualitas air yang buruk ${ }^{18}$.

Perilaku buang air besar sembarangan (BABS) masih banyak terjadi di Indonesia.Di sejumlah daerah, masyarakat masih membuang air besar sembarangan di kali atau sungai. Data Joint Monitoring Program WHO/ UNICEF 2014, sebanyak 55 juta penduduk di Indonesia masih berperilaku buang air besar sembarangan. Berdasarkan data Riset Kesehatan Dasar (Riskesdas) tahun 2013, sebanyak 39-40 juta orang yang BAB sembarangan, termasuk orang yang mempunyai jamban. Riset yang dilakukan UNICEF dan WHO, juga menyatakan lebih dari 370 balita di Indonesia meninggal akibat perilaku buruk dari perilaku $B A B$ sembarangan. Selain penyakit, perilaku BAB sembarangan juga memperbesar risiko yang menghambat pertumbuhan fisik anak-anak ${ }^{19}$.

Berdasarkan tabel di atas, dari 200 responden terdapat 196 responden atau 98\% yang menggunakan jamban ketika Buang Air Besar (BAB), sedangkan 4 responden atau $2 \%$ yang tidak menggunakan jamban ketika Buang Air Besar (BAB). Pada penelitian lainnya yang dilaksanakan pada masyarakat Kelurahan Mata dan Kelurahan Kessilampe bahwa sarana jamban keluarga pada masyarakat Kelurahan Mata dan Kelurahan Kessilampe tahun 2019 sebagian besar telah memenuhi syarat yakni sudah banyak yang mengunakan jamban untuk BAB yakni sebanyak $98 \%$ yang sudah menggunakan jamban.

\section{SIMPULAN DAN SARAN}

Perilaku Hidup Bersih dan Sehat (PHBS)

adalah semua perilaku kesehatan yg dilakukan karena kesadaran pribadi keluarga dan seluruh 
anggotanya mampu menolong diri sendiri pada bidang kesehatan serta memiliki peran aktif dalam aktivitas masyarakat. Pada penelitian di Kelurahan Mata dan Kelurahan Kassilampe didapatkan hasil bahwa pekerjaan dapat memberikan pengaruh besar bagi seseorang karena pendapatan yg dihasilkan dpt menunjang kebutuhannya termasuk phbs selain itu faktor yang berhubungan dengan kualitas phbs adalah pendapatan. Persalinan yang ditolong oleh Tenaga Kesehatan yang mempunyai balita terdapat 118 responden (91\%) yang persalinannya ditolong oleh tenaga kesehatan, sedangkan 11 responden (9\%) tidak di tolong oleh tenaga kesehatatan, yang memberikan Asi ekslusif sebanyak 109 responden $(84,5 \%)$ dan yang tidak sebanyak 20 responden (15,5\%), terdapat 115 responden (89\%) yang melakukan pemantuan pertumbuhan bayi atau balita dan yang tidak sebanyak 14 responden (11\%), responden yang merokok ada 126 responden (63\%) dan yang tidak 74 reponden (37\%). Selain itu sarana air bersih dan penggunaan jamban pada masyarakat sebagian besar telah memenuhi syarat yakni sebanyak 97\% keluarga responden yang memiliki akses sarana air bersih dan $98 \%$ yang sudah menggunakan jamban, ini berati masyarakat sudah memiliki kesadaran yg tinggi tentang PHBS.

Saran penulis bagi para masyarakat Kelurahan Mata Kec. Kasilampe diharapkan agar para masyarakat lebih meningkatkan peran aktifnya dalam menerapkan Perilaku Hidup Bersih Sehat seperti upaya penerapan PHBS dalam rumah tangga, pemilihan penolongan persalinan oleh tenaga kesehatan, pemberian asi pada bayi sebagai asupan pertama, pemakaian posyandu yang baik dan rutin, pengurangan dalam pemakaian rokok, kemudian tidak merokok di sembarang tempat, pemakaian air yang baik yang misalnya dalam rumah tangga air tersebut berasal dari air ledeng (keran) \& menjaga perilaku buang air besar dengan tidak membuang buang air besar di sembarang tempat seperti sungai dan kali. Hal ini juga harus dilakukan dengan kesiapan pemerintah setempat dalam menyediakan / melengkapi fasilitas untuk terlaksananya PHBS dengan baik dalam kehidupan sehari hari di Kelurahan Mata Kec. Kasilampe.

\section{DAFTAR PUSTAKA}

1. Alhidayati, A., \& Asmuliyanti, A. (2016).Perilaku Ibu dalam Memilih Tenaga Penolong Persalinan di Wilayah Kerja Puskesmas Tembilahan Hulu
Tahun 2016. Jurnal Kesehatan Reproduksi, 3(3), 155-162

2. Alihar, F. (2018). Penduduk Dan Akses Air Bersih Di Kota Semarang ( Population And Accsess To Clean Water In Semarang City ). 13(1), 67-76.

3. Apriyanti, L., Widjanarko, B., \& Laksono, B. (2019). Faktor-faktor yang Mempengaruhi Pemanfaatan Jamban Keluarga di Kecamatan Jatibarang Kabupaten Brebes. 14(1).

4. Di, S., Dasar, S., \& Gumpang, N. (2018). Gambaran tentang perilaku hidup bersih dan sehat di sekolah dasar negeri gumpang 01 kartasura sukoharjo.

5. Fadhilah Nur. (2015). PHBS Tatanan Rumah Tangga dan Faktor yang Berhubungan. Jurnal Ilmiah Kesehatan. Vol.5 No.7 Januari 2015.

6. Gunawan, S., Drew, C., Nindi R, D. C., Henyta, \& Sari, K. P. (2018). 133 Penyuluhan "Perilaku Hidup Bersih Sehat (PHBS)" Dalam Rangka Program Tentara Manunggal Masuk Desa (TMMD) Wilayah Kodim 0510 Tigaraksa, Tangerang. Jurnal Bakti Masyarakat Indonesia, 1. file:///C:/Users/ MYASUS/Dow nloads/289765 98-1-PB.pdf

7. Hidayah, N. (2019). Perilaku Hidup Bersih Bersih Sehat Pada Tatanan Rumah Tangga Di Dudun Cun Belut, Desa Cemen Kecamatan Paron Kabupaten Ngawi. file://C:/Users/MY ASUS/Dow nloads/118-360-1-PB.pdf

8. Imroatus, S., \& Maryam, L. (2016). Gambaran Sarana Sanitasi Masyarakat Kawasan Pesisir Pantai Dusun Talaga Desa Kairatu Kecamatan Kairatu Kabupaten Seram Bagian Barat Tahun 2016.

9. Miswanto, Yuniar, N., \& Bahar, H. (2017). Gambaran Perilaku Hidup Bersih Dan Sehat (PHBS) Pada Masyarakat Di Wilayah Kerja Puskesmas Welala Kecamatan Ladongi Kabupaten Kolaka Timur Tahun 2015. file://C:/Users/MY ASUS/Dow nloads/13213664-1-PB.pdf

10. Natsir, M. F. (2019). Perilaku Hidup Bersih Dan Sehat (PHBS) Pada Tatanan Rumah Tangga Masyarakat Desa Parang Baddo. Jurnal Nasional Ilmu Kesehatan ( JNIK ), 1(3), 54-59.

11. Ningrum, P. T., \& Indrayani, R. (2017). Perilaku Merokok Pada Masyarakat Dan Implementasi Kebijakan Kawasan Tanpa Rokok (Ktr ) Di Desa Ajung Kecamatan Kalisat Kabupaten Jember. 5(2), 116-120.

12. Kristanto, H., Sucipto, S., \& Atmojo, D. S. (2018, January). Hubungan Pekerjaan Ibu Dengan 
Kemampuan 8 Indikator Perilaku Hidup Bersih dan Sehat pada Siswa Madrasah Ibtidaiyah Kecamatan Mojoroto Kota Kediri.In Prosiding Seminar Nasional 2018 "Peran dan Tanggung Jawab Tenaga Kesehatan Dalam Mendukung Program Kesehatan Nasional" (pp. 144-148).

13. Liem, Marlina Sumida. \& dkk.(2019). Hubungan Tingkat Pengetahuan lbu Tentang Posyandu Dengan Keaktifan Ibu Mengikuti Posyandu. Volume 4, Nomor 1.

14. Layya, I. (2016). Perilaku Hidup Bersih dan Sehat (PHBS) dalam Tatanan Rumah Tangga Berbasis Kerusakan Akibat Tsunami di Wilayah Kota Banda Aceh.Jurnal Ilmu Kebencanaan: Program Pascasarjana Unsyiah, 3(1).

15. Santoso, A. (2019). Sosialisasi Perilaku Hidup Bersih Dan Sehat (PHBS). 2. file:///C:/Users/MY ASUS/Downloads/168-498-1-PB.pdf

16. Septiani, Hanulan; Budi, Artha; Karbito.(2017). Faktor-Faktor yang Berhubungan dengan Pemberian ASI Eksklusif Oleh Ibu Menyusui yang Bekerja Sebagai Tenaga Kesehatan. Jurnal Aisyah. 2 (2), $159-174$

17. Sri Rahayu Dan Nelly Apriningrum. 2014. Faktor - Faktor Yang Berhubungan Pemberian Asi Ekslusif Pada Karyawati Unsika Tahun 2013. Jurnal IImiah Solusi. Vol. 1 (1)

18. Tosepu. R, dkk. (2016). Kesehatan Masyarakat Pesisir. Kendari: Penerbit Yayasan Cipta Anak Bangsa(YCAB)

19. Zhafirah, N., \& Susanna, D. (2020). Perilaku Hidup Bersih dan Sehat (PHBS) dengan Kejadian Gangguan Pernapasan pada Balita di Kawasan Pesisir Desa Sedari, Kecamatan Cibuaya, Karawang, Jawa Barat Tahun 2018. Jurnal Nasional Kesehatan Lingkungan Global, 1(1). 